\title{
Jak być kochana \\ Kulturowe zapośredniczenie traumy wojennej w filmach z lat 60.
}

\author{
TOMASZ ŁYSAK
}

Psychoanalityczne teorie traumy zakładają istnienie okresu latencji między pierwotnym wydarzeniem traumatyzującym a jego przejawami w psychice ${ }^{1}$. Jeśli przyjmiemy ten mechanizm jako metodę wyjaśniania tużpowojennej historii Polski, władze wyparły wybrane aspekty wojennej historii albo zdecydowały się nie skupiać na poniesionych stratach, proponując $\mathrm{w}$ zamian kulturowe formy narodowej terapii. Wśród traum wojennych należy wskazać zabitych i zaginionych, zniszczone budynki i infrastrukturę, Zagładę (Polacy jako świadkowie, wybawcy i współsprawcy ${ }^{2}$ ), uwięzienie w obozach koncentracyjnych, pracę niewolniczą, przesiedlenia, przymusową emigrację, gwałty, utratę terytorium i zmianę systemu klasowego ${ }^{3}$. Nie mniej istotna była walka komunistycznych władz z antykomunistycznym podziemiem, co utrudniało rozpoczęcie życia na nowo. Bez wątpienia wymienione powyżej krzywdy miały różny status po wojnie: część z nich podlegała oficjalnemu upamiętnieniu, zaś inne wypierano lub nie zauważano ich, dopóki nie zostały odkryte na nowo w ostatnich dwóch dekadach ${ }^{4}$. Analizy historyczne skupiają się na latach 40. i 50., w tym okresie poszukiwano także źródeł współczesnej tożsamości Polaków. W akademickiej historii ten okres nazwano czasem „wielkiej trwogi" 5 , pełnym niepewności, w którym jednostki poranione przez wojnę musiały stawić czoło nowym formom przemocy. Żydowscy ocaleńcy stanowili odrębną grupę ze względu na pochodzenie etniczne, chęć odzyskania utraconego majątku, rzeczywisty lub domniemywany akces do władz komunistycznych ${ }^{6}$. W kontekście medycyny terapeuci zaczęli dostrzegać psychologiczne echa uwięzienia w Auschwitz-Birkenau wśród byłych więźniów w latach $60 .{ }^{7}$ Przeprowadzone niedawno badanie psychologicznego obciążenia II wojną światową wśród Polaków ujawnia wysoki poziom PTSD ${ }^{8}$. Kombatanci, więźniowie obozów koncentracyjnych i partyzanci zrzeszali się $\mathrm{w}$ grupach wsparcia pod pieczą państwa, jednakże inni poranieni przez wojnę sami musieli radzić sobie z własną przeszłością. $Z$ drugiej strony, jak dowodzi Svenja Goltermann ${ }^{9}$, nie należy bezrefleksyjnie przykładać pojęcia „traumy” do opisu stanu psychicznego wojennych ocaleńców (dodałbym też sprawców), lecz widzieć w nim produkt rozwoju psychiatrii i dyskursu medycznego. Nie da się ukryć, że filmy fabularne i literatura wyprzedziły psychiatrię w opisywaniu i pokazywaniu symptomów posttraumatycznych, chociaż próżno w nich szukać metadyskursu terapeutycznego.

Gloryfikacja heroizmu kosztem ukrycia ciemnych kart historii stała się podstawową narracją oficjalnej historii wojny ${ }^{10}$. Dlatego nie dziwi fakt, że filmy fabularne w latach 40., np. Zakazane piosenki (reż. Leonard Buczkowski, 1946) i Ostatni etap (reż. Wanda Jakubowska, 1947), przedstawiały podnoszące na duchu 
narracje o oporze i wytrwałości, odpowiednio w okupowanej Warszawie i obozie koncentracyjnym Auschwitz-Birkenau. Wprowadzenie socrealizmu i ograniczenia narzucone przez stalinizm zablokowały szczerą dyskusję o niedawnej przeszłości. Polska szkoła filmowa podważała mity narodowe pod koniec lat 50., reinterpretując rolę powstania warszawskiego, los polskich Żydów i antykomunistycznego podziemia. Mimo że władze komunistyczne same były źródłem psychologicznego niepokoju, przyjęły rolę lekarza, który leczy konflikty społeczne celuloidowym heroizmem i wzbudza dumę narodową. Niewiele było okazji do wygłoszenia zdania odrębnego, krytykującego te filmowe przedstawienia wojny jako zasłonę dymną ukrywającą nieheroiczne zachowania Polaków pod okupacją niemiecką.

Celem tego eseju jest nakreślenie form przedstawiania pamięci traumatycznej w filmach z lat 60. Chciałbym się skupić na trzech obrazach: Dziś w nocy umrze miasto (reż. Jan Rybkowski, 1961), Jak być kochana (reż. Wojciech Jerzy Has, 1962) i Pasażerka (reż. Andrzej Munk i Witold Lesiewicz, 1963). Przedstawione przez Rybkowskiego świadectwo nalotu bombowego na Drezno podzieliło krytyków i wkrótce uległo zapomnieniu ${ }^{11}$. Hasowi i Munkowi udało się odcisnąć piętno na polskim kinie, zadali też istotne pytania dotyczące pamięci wojny i jej niesłabnącej wagi dla powojennych pokoleń. Te trzy filmy łączy wspólny element, to jest przedstawienie traumy jako wydarzenia i symptomu. Co więcej, reżyserzy ci nadają prawo odczuwania psychologicznego zranienia różnym aktorom $\mathrm{w}$ teatrze historii ${ }^{12}$. Judith Butler podkreśla: odprawiamy żałobe po danym życiu, a utrate innego przyjmujemy z chłodna obojętnością ${ }^{13}$. Dlatego też wskazanie ofiar i osób straumatyzowanych przez wojnę ma przyczyny polityczne. Chociaż próżno w filmach tych szukać objaśnienia traumatycznych wydarzeń i ich echa w dyskursie psychoanalitycznym lub psychiatrycznym, sposób zobrazowania tychże wydarzeń odkrywa mechanizmy kulturowej polityki traumy. Zastosowanie psychoanalitycznego dyskursu studiów nad traumą ma tutaj trzy powiązane ze sobą cele: ocenę poziomu rozumienia efektów wojennych stresorów traumatycznych w latach 60., odróżnienie uznawanych form przeżycia/śmierci od psychologicznego zranienia niegodnego upamiętniania i potraktowanie kulturowych przedstawień traumy jako symptomów szerszych procesów kulturowych i społecznych. Omawiane tu filmy posłużą jako studia przypadku, na podstawie których dokonam spekulatywnej rekonstrukcji (nienapisanego w latach 60.) podręcznika terapeutycznego.

\section{Przeżyć w Dreźnie: Dziś w nocy umrze miasto}

Warkot silników lotniczych, zapowiadający nalot bombowców na miasto, stał się symbolem walki aliantów z Hitlerem, a bombardowania miały złamać morale cywilów. Naloty dywanowe traktowano na Zachodzie jako nieodzowny koszt zwycięstwa. Tę perspektywę podkreśla pełnometrażowy dokument Errola Morrisa Mgly wojny (The Fog of War, 2003), oparty na wywiadzie z Robertem McNamarą ${ }^{14}$, który wyjaśnia strategiczne i statystyczne zasady atakowania cywilów. Ludzki koszt bezwzględnego niszczenia miast i ludności opisuje Kurt Vonnegut w na wpół autobiograficznej powieści Rzeźnia numer pięć ${ }^{15}$, zaś W. G. Sebald komentuje literackie opisy tego technologicznego piekła i jego ofiar w On the Natural History of Destruction ${ }^{16}$. Viktor Klemperer - profesor literatury francuskiej i Niemiec żydowskiego pochodzenia - w swoim dzienniku przedstawia nalot jako zda- 


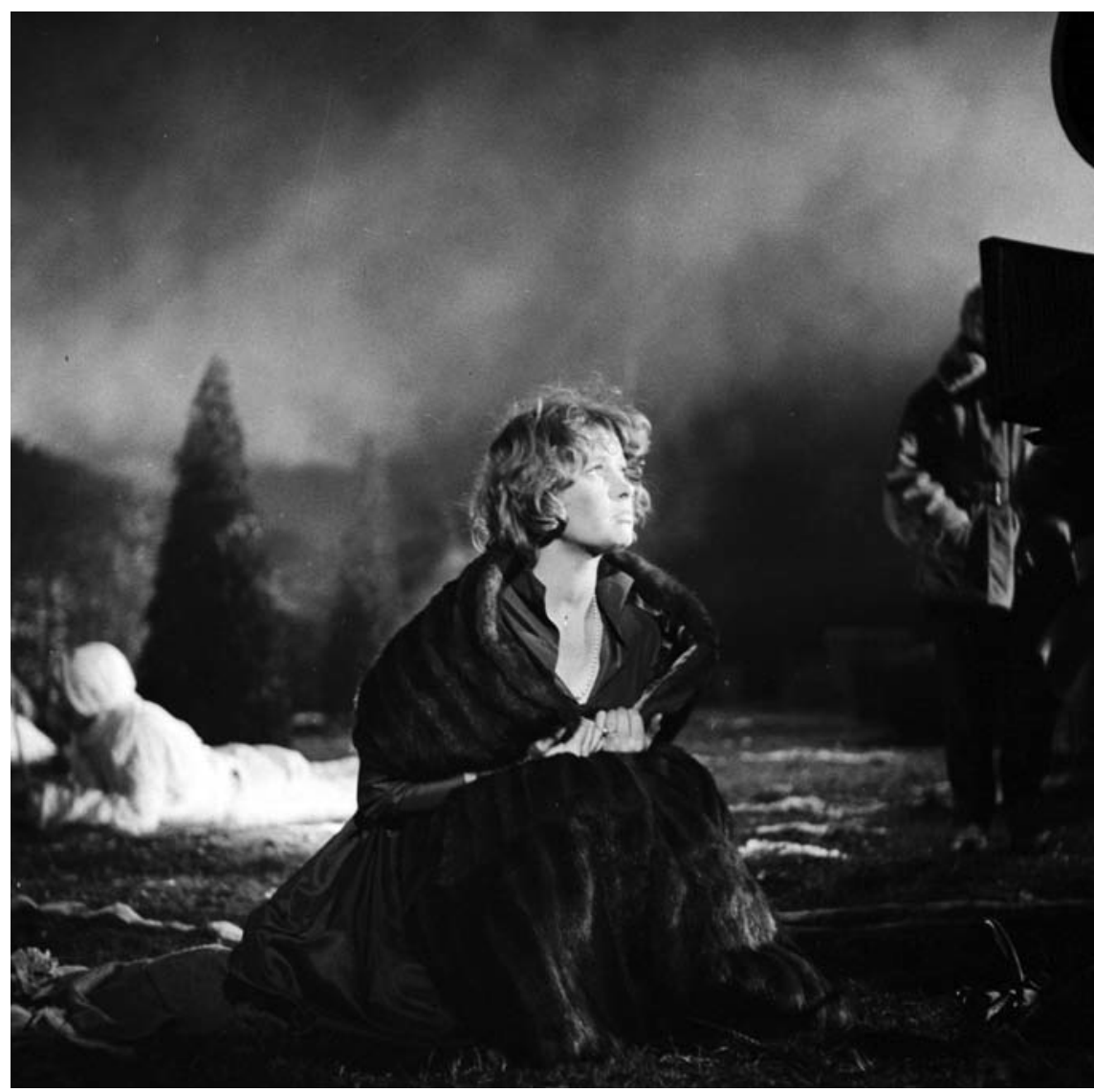

Dziś w nocy umrze miasto, reż. Jan Rybkowski (1961)

rzenie, które uratowało go przed deportacją i niechybną śmiercią ${ }^{17}$. Modernistyczna wizja płonącego Drezna sfilmowana przez Rybkowskiego powstała przed wieloma z powyższych tekstów i pokazuje zniszczenie miasta z perspektywy polskiego więźnia obozu koncentracyjnego - uciekiniera z pociągu do Dachau. Wybór tematu przez Rybkowskiego wydaje się zaskakujący, jednakże w NRD wykorzystywano bombardowanie Drezna, aby potępić zachodni imperializm ${ }^{18}$. Ponadto reżyser osobiście doświadczył bombardowania.

Atak na bezbronne ofiary i zniszczenie kultury w momencie, gdy wynik drugiej wojny światowej byt już przesądzony, wykorzystywano dla doraźnych celów politycznych ${ }^{19}$. W podobnym tonie autor reportażu w „Filmie” nazywa bombardowanie nie wyjaśnion [a] dotąd tajemnic [a] drugiej wojny światowej ${ }^{20}$. Ujęcie wprowadzające ukazuje pociąg pospieszny pędzący przez stację kolejową w Dreźnie; obraz ten zestawiono z obrazem innego pociągu, przewożącego brudnych więźniów w wagonach bydlęcych w jeszcze nieznanym kierunku. Więźniowie planują ucieczkę i umawiają się na spotkanie w restauracji Astoria w Dreźnie. Podczas ucieczki ginie jeden z nich, przez co główny bohater Piotr zostaje zdany sam na siebie. Tempo poruszania się pociągów to komentarz do niemieckiego projektu 
modernizacji: prędkość ekspresu okupiono niespieszną biopolityką pracy przymusowej ${ }^{21}$. Ta wizualna metafora pokazuje, że nazistowska modernizacja reguluje prędkość zmian społecznych: niepożądane jednostki odstawiono na boczny tor, aby nie zwalniały tempa zmian.

Film przedstawia Drezno przed nalotem jako bezpieczne schronienie dla ofiar bombardowania innych miast w Niemczech. Kobietę w szoku pourazowym, skarżącą się na wycie syren przeciwlotniczych dźwięczące w jej głowie, inna bohaterka diagnozuje jako cierpiącą $\mathrm{z}$ powodu symptomów bombardowania Hamburga w lipcu i sierpniu 1943 roku. Ocalała powraca do sceny pierwotnej traumy za sprawą halucynacji słuchowych i wspomnienia o burzy ognia. W końcu ta natrętna fantazja przekształca się w prawdziwy nalot. Warto podkreślić, że u Rybkowskiego z powodu traumy cierpią głównie kobiety.

Piotr milczy na temat obozu, mimo że Drezno przypomina mu przedwojenne życie. Jako artysta i intelektualista $\mathrm{z}$ filozoficznym dystansem podchodzi do cierpienia niemieckich mieszkańców i, w mniejszym stopniu, obywateli innych państw, najprawdopodobniej robotników przymusowych. Podczas nalotu oskarża Hitlera o spowodowanie upadku kultury niemieckiej. Włoski artysta cyrkowy Vittorio jest inną ofiarą szoku pourazowego, niemą i bezradną po doświadczeniach wielu nalotów w różnych miastach Europy. To żona przejęła odpowiedzialność za jego bezpieczeństwo, gdyż sam utracił instynkt samozachowawczy. W jego przypadku symptomy obejmują dezorientację, zaburzenia mowy i utratę celu. Vittorio i kobieta z Hamburga to podręcznikowe przypadki szoku pourazowego, cierpią z powodu halucynacji i utracili kontrolę nad swoim życiem. Co więcej, ich trauma jest „niewypowiadalna" - o ich cierpieniach mówią nam inni.

Pod względem wizualnym film można podzielić na dwie części: przed bombardowaniem i w jego trakcie. W tej pierwszej wykorzystano realistyczne konwencje filmowania i narracji filmowej, zaś druga za pomocą kontrastowego oświetlenia wydobywa sylwetki bohaterów na tle płonącego miasta. W czasie drugiej fali bombardowania Piotr i Magda (młoda, rozkapryszona Niemka) schronili się na brzegu rzeki, narażając się na trafienie bombą. W scenie przypominającej otwarcie Hiroszimy, mojej miłości Alaina Resnais'go (1959) Piotr zasłania Magdę własnym ciałem ${ }^{22}$. Ich splątane ciała przypominają kochanków w akcie miłosnym. Cielesna bliskość to znak kruchości w obliczu technologicznej wojny. Trzeba podkreślić, że Magda przedstawiana jest jako samolubna przedstawicielka klasy uprzywilejowanej, narzekająca, że przez nalot nie pojechała na narty. Przypomina to typową komunistyczną krytykę zachodniego kapitalizmu i konsumpcjonizmu (za sprawą których część niemieckiego społeczeństwa była ślepa na realia systemu totalitarnego), ukazuje jednak transformacyjny model traumy. Dla bogatej Niemki, dotychczas chronionej przed negatywnymi aspektami wojny, nalot to rana, doświadczenie bliskości śmierci. Pozbawiona komfortu, jaki zapewniał jej status materialny i społeczny, znalazła się w rękach obcego. Niemniej nie padła ofiarą narzuconego przez nazistów zakazu kontaktów intymnych z obcokrajowcami (Rassenschande) ani seksualnej przemocy zwycięskiej Armii Czerwonej. Rycerska opiekuńczość Piotra przesłania podwójne tabu: zhańbienia rasy i traktowania niemieckich kobiet jak łupów wojennych. Rybkowski wyjaśnia, że różnice między Piotrem i Magdą w końcu znikają z powodu: uczuci[a] fizycznej wspólnoty przed grożącym niebezpieczeństwem $^{23}$. 


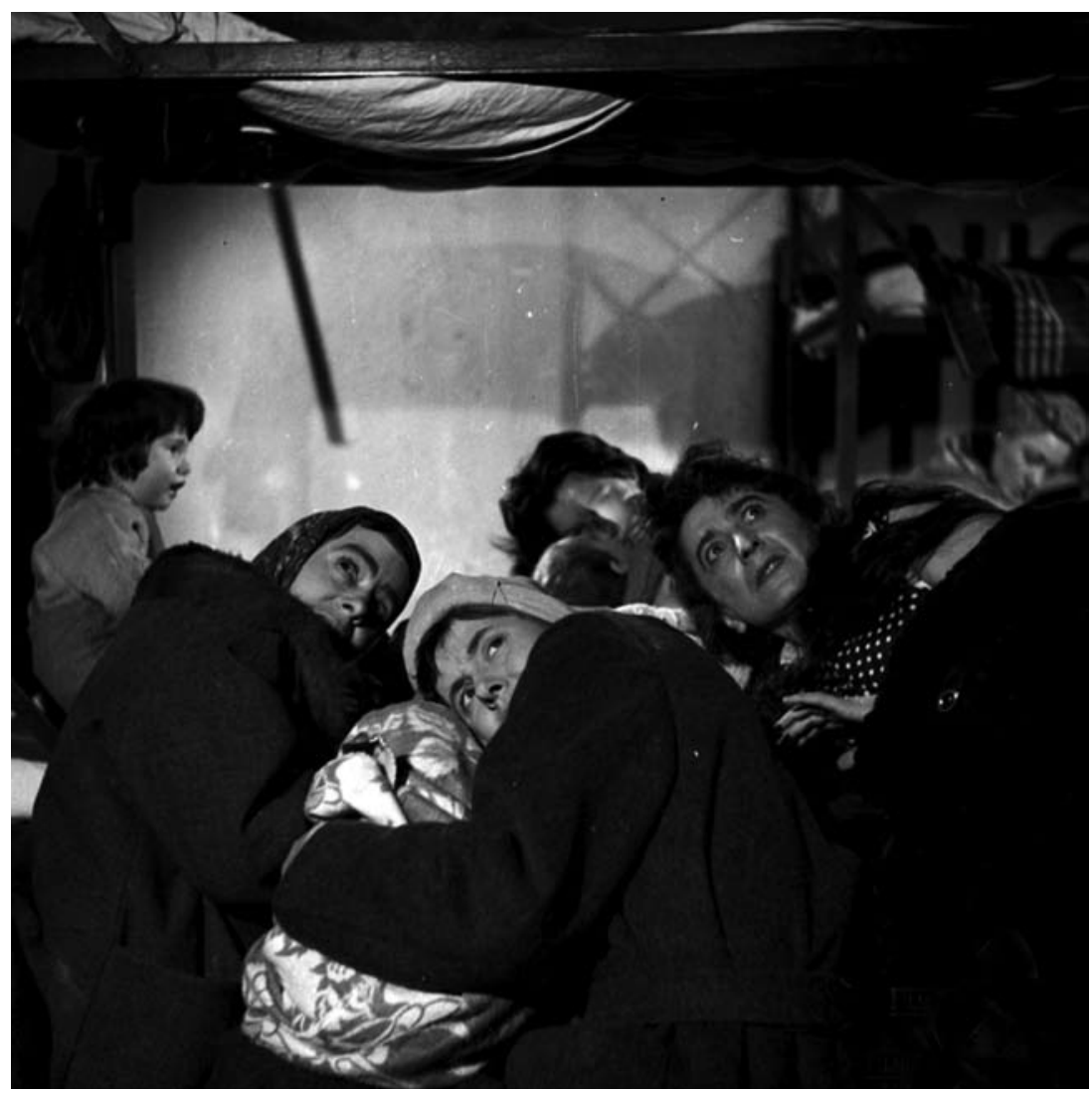

Dziś w nocy umrze miasto, reż. Jan Rybkowski (1961)

Jako że film kończy się widokiem płonącego Drezna, nie występują w nim retrospekcje, zamiast tego widownia ogląda filmową rekonstrukcję „śmierci miasta”. Odbiorcom oszczędzono jednak obrazu martwych ciał lub płonących zwłok, w zamian kamera rejestruje rany zadane miastu. W jednej ze scen oglądamy zabandażowanych rannych, cierpiących z powodu oparzeń, lecz brakuje wyjaśnienia, kto opatrzył ich rany i dlaczego chodzą po zrujnowanych ulicach w tym stanie. W istocie trudno odróżnić te ujęcia od inscenizowanego filmu dokumentalnego przedstawiającego ofiary wybuchu nuklearnego w Hiroszimie, mojej miłości. Podkreślanie doświadczenia bliskości śmierci przez Piotra i Magdę służy wydobyciu traumy psychicznej, a nie fizycznego zranienia. Estetyczna strategia przedstawiania technologicznego piekła ustanawia realizm traumatyczny oparty na wizji płonącej Hiroszimy Resnais'go. Te odniesienia do estetyki innych filmów nie wyjaśniają jednak, dlaczego polscy widzowie mieliby współczuć losowi niemieckich cywilów i zagranicznych robotników przymusowych w Dreźnie. Ich cierpienia przywodziły na myśl ofiary nalotów Luftwaffe w Polsce. Wskazywały także na wspólne człowieczeństwo wszystkich ofiar wojny widzianej jako ludzka tragedia i przyczyna cierpienia Innego. Rybkowskiemu nie udało się jednak przekonać widzów do pojednawczej wizji ponadnarodowej natury cierpienia, a modernistyczna estetyka oparta na filmie Resnais'go nie trafiła do części krytyków ani do zwykłych widzów. 


\section{Jak być kochana: dwa rodzaje autoterapii}

Jak być kochana odczytywano zazwyczaj jako historię nieodwzajemnionej miłości młodej aktorki do aktora przekonanego o swoim geniuszu scenicznym. Felicja ${ }^{24}$ robi wszystko co w jej mocy, aby uratować ukochanego w czasie wojny, ukrywając go w swoim krakowskim mieszkaniu przez pięć lat. Pomimo jej poświęceń i ryzyka kary śmierci za ukrywanie poszukiwanego Wiktor Rawicz pozostaje obojętny na jej uczucia i gardzi sytuacją, w jakiej się znalazł. Usycha pozbawiony teatralnego aplauzu, oskarża Felicję o spowodowanie swojego nieszczęścia. Paradoksalnie, to Wiktor wymaga pocieszenia po zgwałceniu Felicji przez dwóch niemieckich żołnierzy w jej mieszkaniu. Gdy kończy się wojna, opuszcza dom bez podziękowania gospodyni, zaś aktorka ponosi karę za utrzymywanie tej historii w sekrecie. Skazano ją na pięcioletni zakaz występowania za pracę w niemieckim teatrze, którą podjęła, aby zdobyć środki na utrzymanie ukochanego. Po zniesieniu zakazu ich losy się odwracają: aktorka zdobywa sławę, grając żonę w popularnym słuchowisku radiowym, a Wiktor nie jest w stanie występować. Stacza się, by w końcu popełnić samobójstwo w mieszkaniu Felicji. Przed skokiem z okna pije w barze, chwaląc się bohaterskimi czynami w konspiracji. Tę fikcyjną historię postrzegam jako przykład fetyszyzmu narracyjnego, to jest koherentnej narracji służącej ukryciu najbardziej traumatycznego wydarzenia ${ }^{25}$. Z drugiej strony cierpienie Rawicza jest skutkiem podstępnej traumy, to znaczy ciągłego uczucia bezradności, a nie pojedynczego czynnika traumatycznego ${ }^{26}$. Scenariusz każe nam wierzyć, że powojenne zachowanie bohatera wynika z niedostatków jego charakteru, a nie okoliczności przeżycia. Tym samym podstępna trauma staje się symptomem pozbawionym przyczyny, odciętym od codziennego uczucia strachu i wstydu ${ }^{27}$.

Film przedstawia dwa modele radzenia sobie z traumą: heroiczny i wstydliwy. Felicja przezwycięża przeszłość, cierpi z godnością i jedynie z rzadka poddaje się sile wspomnień. Wiktor jest „niedojrzały”, niewdzięczny, samolubny i żałosny, a jednocześnie pragnie być bohaterem we własnej opowieści. Sukces Felicji w opanowaniu traumy pokazano na pokładzie nowoczesnego samolotu, którym udaje się na dwutygodniowe wakacje do Francji na zaproszenie wielbicielki. Podczas pierwszego lotu w życiu dodaje sobie animuszu koniakiem, Wiktor natomiast zginął zamroczony wódką ${ }^{28}$. W filmie przeciwstawiono te dwa alkohole, a koniak konotuje nowoczesność i powściągliwość ${ }^{29}$. Losy bohaterów mają przeciwne wektory: Felicja wznosi się, a Wiktor wyskakuje z okna. Publiczne picie alkoholu przez kobietę wyjaśniono lękiem przed lataniem, nie dzieli się też swoją historią z innymi pasażerami ${ }^{30}$. Alkohol służy Felicji do otwarcia się przed sobą.

Żaneta Jamrozik zauważa, że kobieta unika sytuacji, w których oczekiwano by od niej uwolnienia emocji, a jej zachowanie nigdy nie staje sie ,prywatne” ${ }^{31}$. Zachowanie to można zanalizować w kategoriach psychoanalitycznych jako psychiczne otępienie, strategię obronną chroniącą jej psychikę przed nadmiarem afektu. W samolocie wspomina wojnę w serii retrospekcji, tylko na chwilę tracąc opanowanie. Mężczyzna siedzący obok niej (polski profesor medycyny na emigracji) wspomina o swojej służbie jako pilota w RAF-ie. Na Felicji takie technologiczne bohaterstwo nie robi wrażenia, szczególnie w porównaniu z tym, co musieli znosić Polacy pod okupacją. Film ustanawia hierarchię cierpienia: nagrodzono bezinteresowne poświęcenie Felicji, umniejszono technologiczny heroizm 


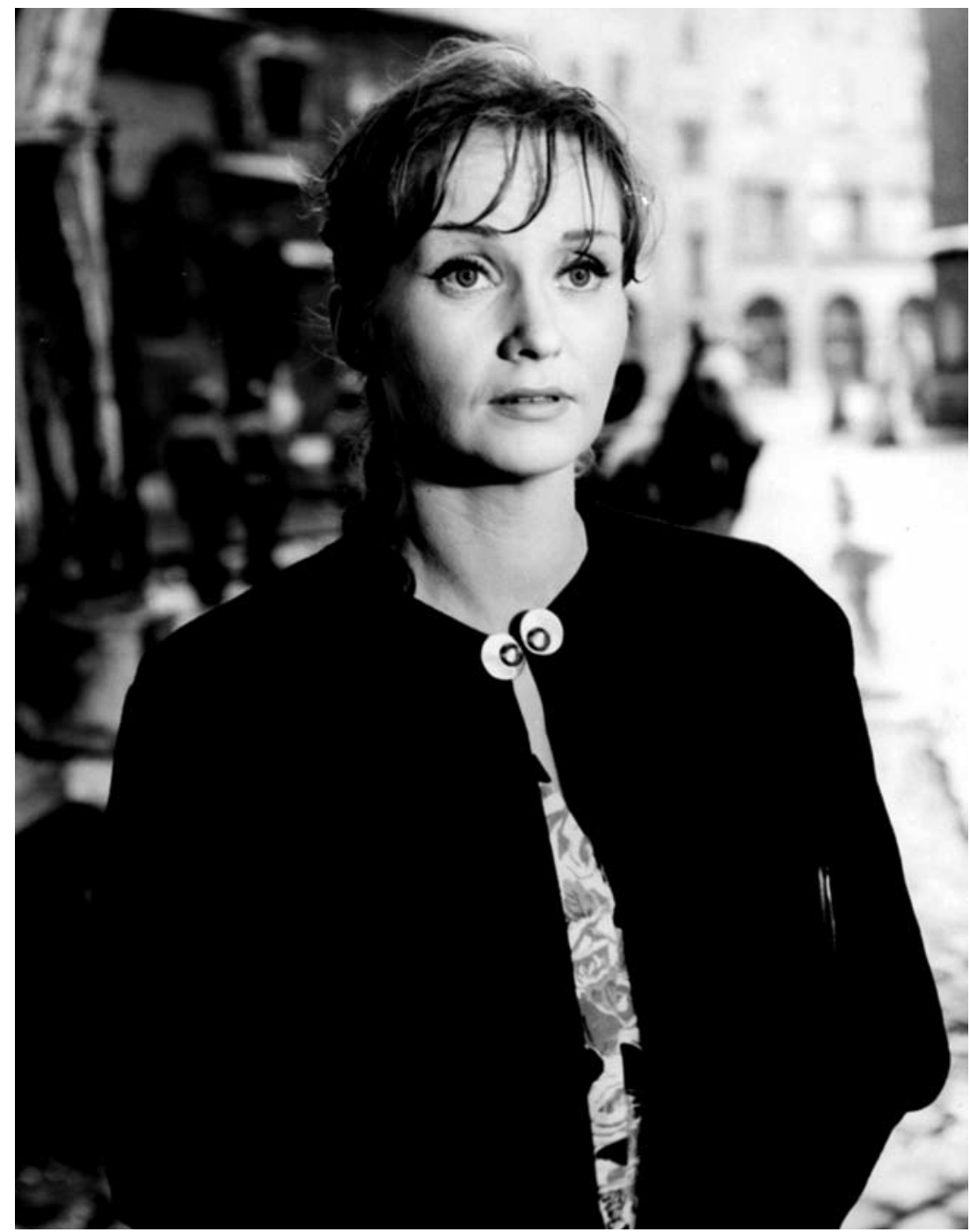

Jak być kochana, reż. Wojciech Jerzy Has (1962)

byłego pilota, a wstydliwy brak działania Wiktora ukazano jako zgubny. Heroizm aktorki nie ma nic wspólnego z walką zbrojną, podziemiem lub konspiracją. Wprost przeciwnie: wynika ze źle ulokowanego uczucia.

Ukrytym sensem Jak być kochana jest przeświadczenie, że autoterapia urazów psychicznych to warunek konieczny modernizacji. Skupianie się na przeszłości, wypieranie jej i rozdrapywanie ran doprowadziły Wiktora do samobójstwa. Przedstawiono go w złym świetle jako nie tylko niegodnego uczucia Felicji, ale także z powodu cierpienia psychicznego. Zaczął się ukrywać po ulicznej egzekucji kolegi z teatru, zabitego rzekomo przez ruch oporu za współpracę z Niemcami. Chichot losu sprawił, że jego tuché - Lacanowski ślepy los ${ }^{32}$ - to wzięcie go za bohatera, 


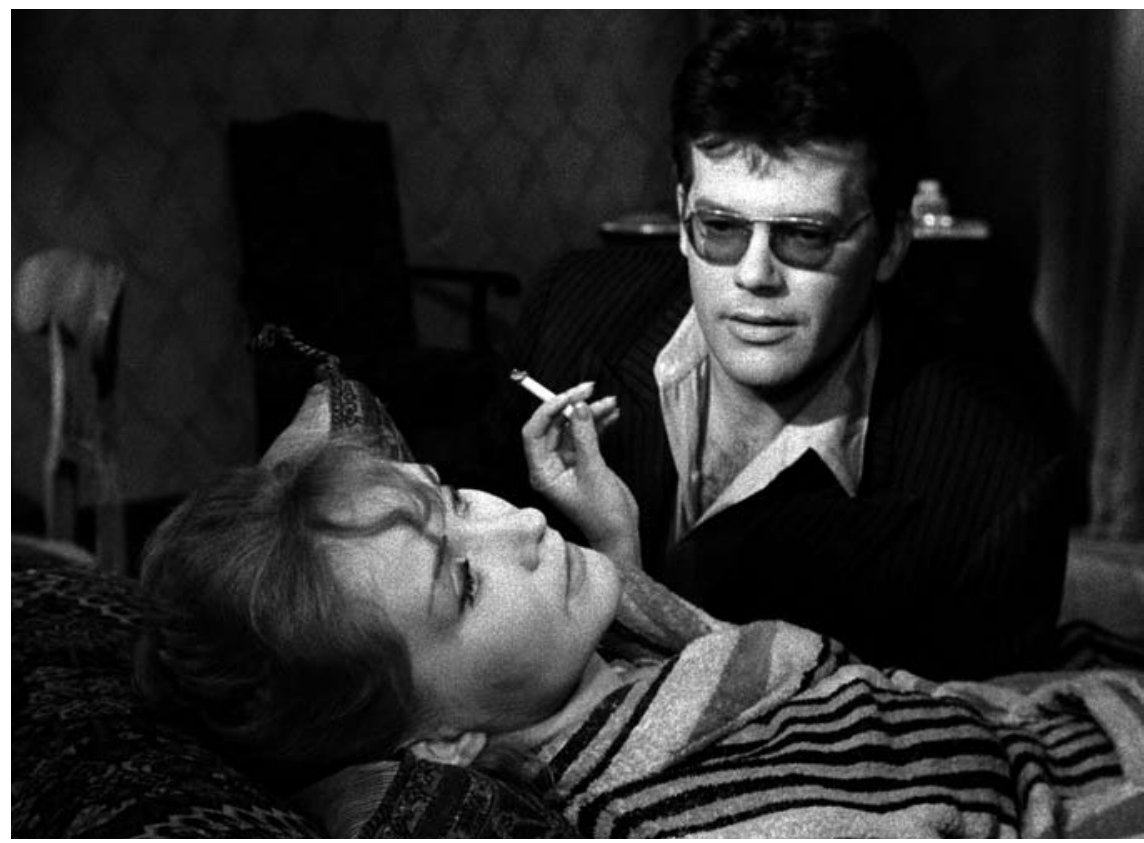

Jak być kochana, reż. Wojciech Jerzy Has (1962)

przez co musiał zniknąć do końca wojny. Jego teatralny heroizm w kawiarni Niemcy wzięli za autentyczny przejaw oporu. Po wojnie traci kontrolę nad własnym życiem - staje się kobieciarzem i topi smutki w alkoholu. Chociaż upijanie się akceptowano społecznie jako formę radzenia sobie, Wiktor posuwa się za daleko. Zaproponowana przez Antoniego Kępińskiego analiza stylów picia mogłaby posłużyć jako recenzja Jak być kochana. Psychiatra mówi m.in. o piciu „heroicznym”, w którym duże dawki alkoholu wyzwalają niebezpieczne zachowania: odwaga po spożyciu bliska jest zachowaniom samobójczym, a upijanie się do nieprzytomności ją wzmaga. Kępiński uważa, że ten styl picia to polska cecha narodowa, gdyż brak umiaru sprawia, że nawet osoby, które mają ochotę na jednego drinka, piją na umór ${ }^{33}$. Alkohol zmniejsza potrzebę odpowiedzenia na palące pytania dotyczące własnego samoobrazu i sprawia, że osoba pod wpływem alkoholu korzystniej ocenia własną inteligencję i odwagę. Psychiatra ostrzega jednak, że zgłębianie zakamarków własnej duszy jest bezcelowe, gdyż alkohol sprzyja pogrążeniu się $\mathrm{w}$ mroku ${ }^{34}$. W tym procesie wódka staje się farmakonem, trucizną, która chroni pijącego przed zadaniem sobie śmierci. Połączenie heroizmu ze skłonnościami samobójczymi zmusza Wiktora do odebrania sobie życia. Alkoholowa autoterapia (typowa dla polskiej kultury) podejmowana jest przed skontaktowaniem się ze specjalistą zdrowia psychicznego ${ }^{35}$. Chociaż alkohol zagłusza u bohatera symptomy posttraumatyczne, to spowodowane jego spożyciem osłabienie cenzury psychicznej znosi ochronne wyparcie. Stąd porażka Wiktora w samodzielnym radzeniu sobie z przeszłością wskazuje na potrzebę stworzenia innej kultury terapeutycznej, w której trzeźwa ocena przeszłości prowadzi do uleczenia psyche. Warto dodać, że w żadnym z omawianych tutaj filmów postaci nie zgłaszają potrzeby wsparcia psychicznego przez inne osoby, nie wspominając o formalnej terapii. 




Jak być kochana, reż. Wojciech Jerzy Has (1962)

Posttraumatyczna retrospekcja rozpoczyna serię reminiscencji: obrazowi otwartego okna towarzyszy kobiecy krzyk. Niemniej resztę filmu opowiedziano przy pomocy tradycyjnych środków z przewidywalnym przejściem od powojennej rzeczywistości do wspomnień o wojnie. Eberhardt porównuje siłę zabiegu narracyjnego Hasa do retrospekcji Resnais'ego w Hiroszimie, mojej miłości ${ }^{36}$. Bez wątpienia historia przyjmuje punkt widzenia Felicji (retrospekcja to forma fokalizacji). Jej dobroć powstrzymuje ją przed oskarżeniem Wiktora o niewdzięczność. Nie jest tajemnicą, że ukrywający często narzekali na powojenne zachowanie ukrywanych ${ }^{37}$. To zwykle polskim Żydom zarzucano niewdzięczność wobec ich wybawców, jeśli nie mogli lub nie chcieli odpłacić za dar życia ${ }^{38}$. Istnieje istotna różnica między ukrywaniem Żydów a przechowywaniem aktora: Żydzi zwykle pokrywali koszty jedzenia i opieki, zaś Felicja udziela schronienia z miłości. Z punktu widzenia psychologii pozbawienie możliwości działania to przyczyna negatywnych uczuć (u)ratowanych. Bez wątpienia skargi na niechcianą zależność, krytyka gospodarzy za złe traktowanie i potrzeba zajęcia się własnym życiem po wyzwoleniu brane były za niewzięczność. 
Aktorka Barbara Krafftówna upatruje źródło nieszczęścia Felicji w cechach charakteru Wiktora: byt człowiekiem bezwartościowym, zerem ${ }^{39}$. Jej uczucie do tego niegodnego mężczyzny opiera się na braku, co powoduje awersję i niewdzięczność. Jego upadek jest związany z niemożnością sprostania wyidealizowanemu obrazowi, jaki stworzyła sobie Felicja. Dla niej ratunek wiązał się ze złamaniem zasad społecznych ${ }^{40}$ (,współpracy z Niemcami”), bez protestu przyjęła niezasłużoną karę, aby nie zburzyć legendy ukochanego. W tej historii doszło do odwrócenia ról: „tchórza” wzięto za bohatera (dzięki zmyślonym historiom i dyskrecji Felicji), bohaterkę ukarano za zdradę. Władza symboliczna tych postaci zależy od umiejętności snucia narracji i autoprezentacji. Określenia „,bohater/tchórz/zdrajca” zależą od tego, jak wiele ujawniono o czyjejś przeszłości. Z drugiej strony za przyczynę upadku Wiktora uznano jego charakter, a nie wojenne przeżycia. Scenariusz Jak być kochana umniejsza znaczenie okoliczności ocalenia dla rozwoju symptomów posttraumatycznych, traktując je jako wynik psychologicznej predyspozycji i wcześniejszych uwarunkowań.

\section{Pasażerka: kobieta-sprawca i lęk przed normalizacją}

Niespotykany duet kobiet przyciąga uwagę w klasycznym filmie o fabryce śmierci w Birkenau. Pasażerka Andrzeja Munka to adaptacja słuchowiska radiowego (wydanego też jako powieść) Zofii Posmysz, która oparła opowieść na własnych doświadczeniach z obozu ${ }^{41}$. Była strażniczka SS wchodzi na pokład liniowca zmierzającego z Argentyny do Niemiec, gdzie ku swemu zaskoczeniu widzi kobietę przypominającą jej więźniarkę z Auschwitz-Birkenau. To przypadkowe spotkanie wyzwala serię retrospekcji, w których Liza wyjaśnia mężowi historię służby w obozie koncentracyjnym, a później robi rachunek sumienia. Śmierć reżysera w wypadku samochodowym odcisnęła piętno na filmie: zmontowano jedynie sceny nakręcone w obozie, a wspomnienia na pokładzie oddano montażem fotosów z komentarzem z offu. Witold Lesiewicz - asystent reżysera - skończył film, korzystając z materiałów nagranych przed śmiercią Munka. Niecodzienna forma to zarówno reprezentacja, jak i symptom traumy. W niesamowitym odwróceniu medium fotograficzne ilustruje pokłosie przemocy, zaś powrót do „sceny pierwotnej” ludobójstwa odbywa się za sprawą ruchomych obrazów. Z drugiej strony takie niesamowite odwrócenia pokazują przeszłość obozu koncentracyjnego ze szczególnej perspektywy. Z racji podejmowanego tematu i niespotykanej formy Pasażerkę należy poddać lekturze pod kątem traumy, biorąc pod uwagę traumatyczne spotkanie, retrospekcję i mechanizmy przywoływania przeszłości.

W latach 60. powojenne spotkania z oprawcami były częstym tropem definiującym pamięć o wojnie. Chociaż Rozmowy z katem Kazimierza Moczarskiego wydano dopiero w latach 70., Moczarski spisał je w 1956 r. Byli więźniowie Auschwitz-Birkenau spotykali prześladowców na salach sądowych, świadcząc o ich zbrodniach; najistotniejszą z takich okazji był proces załogi obozu we Frankfurcie (1963-1965). Filmy dokumentalne wzywały do czujności podczas wizyt w RFN, gdzie nieukarani sprawcy cieszyli się wolnością, np. Powszedni dzień gestapowca Schmidta (reż. Jerzy Ziarnik, 1963), w którym widownię poproszono o baczne przyjrzenie się fotografiom gestapowca, gdyż ten może się teraz podawać za praworządnego obywatela. Ta rada miała jednak niewielkie znaczenie prak- 


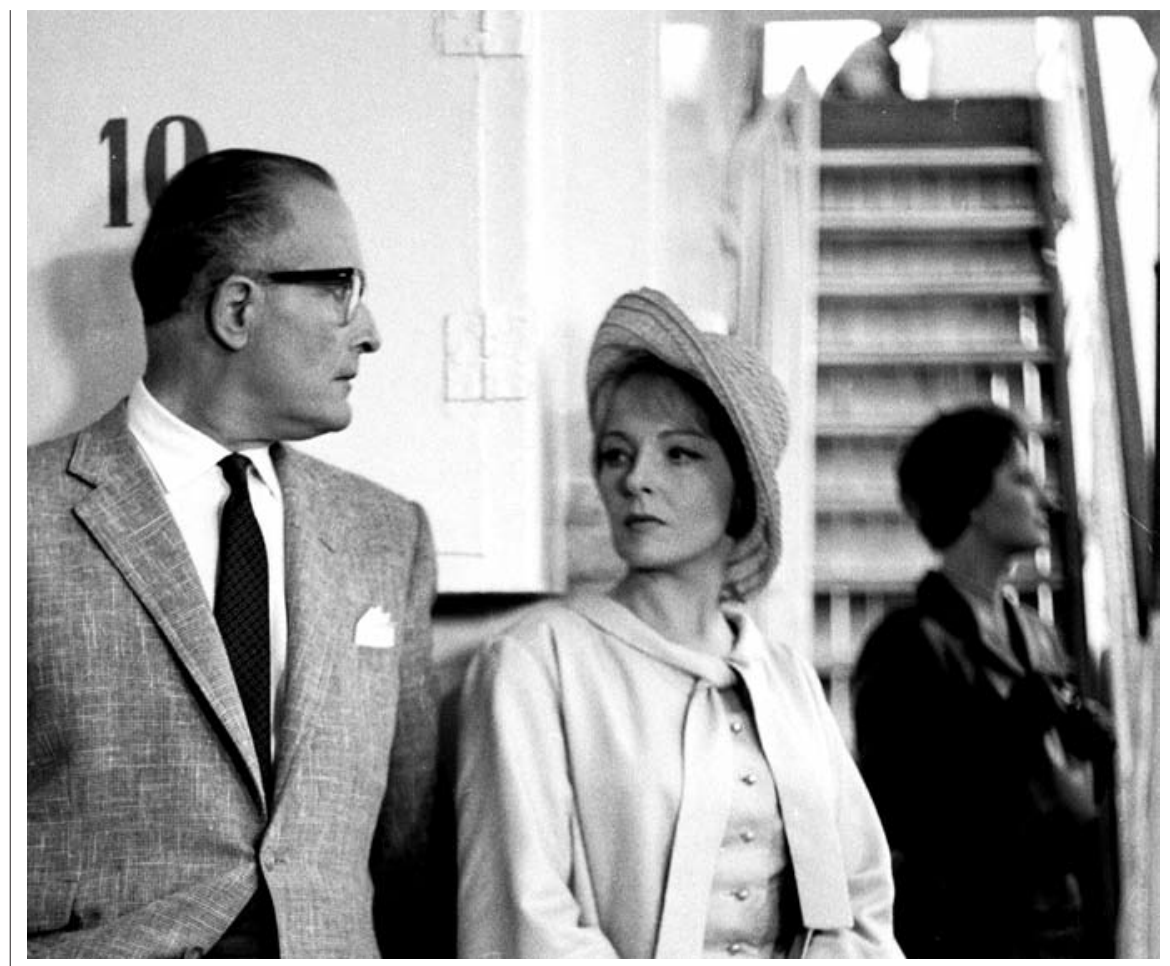

Pasażerka, reż. Andrzej Munk, Witold Lesiewicz (1963)

tyczne, jako że znakomita większość Polaków nie miała wtedy szansy odwiedzić Niemiec zachodnich. Sprawcy pojawiali się też w Polsce osobiście, aby odzyskać skradzione skarby. Taki scenariusz znajdujemy w filmie fabularnym Ostatni świadek (reż. Jan Batory, 1969), w którym były więzień obozu koncentracyjnego uniemożliwia SS-manom, podającym się za ornitologów, zagrabienie skarbu zakopanego w jaskini. Zazwyczaj sfokalizowana narracja przyjmuje perspektywę ocaleńca albo ostrzeżenie kierowane jest do ogółu Polaków. Wyobrażone spotkanie służy podsycaniu lęku, a nie opisowi możliwego wydarzenia. Z drugiej strony, Posmysz ,usłyszała" głos byłej strażniczki w przypadkowej rozmowie dwóch Niemek na placu de la Concorde w Paryżu, dokąd poleciała służbowo jako dziennikarka, aby opisać nowe połączenie rejsowe LOT-u ${ }^{42}$.

W Pasażerce Liza jest niezdolna do szczerej konfrontacji z własnymi wspomnieniami ani przed mężem, ani przed sobą. Jeśli przyjąć perspektywę socjopolityczną, chodziłoby tu o ostrzeżenie przed przedawnieniem się zbrodni hitlerowskich. Wyprzedzała o dekady niedawną dyskusję o traumatyzacji sprawców ${ }^{43}$, Pasażerka tylko raz pokazała słabość Lizy. SS-manka przygląda się pochodowi małych dzieci, schodzących po schodach do komory gazowej, nieświadoma, że jej „moment słabości” dostrzega polska więźniarka Marta. Liza nie wyjaśnia, czym była jej słabość, lecz możemy założyć, że odczuwała współczucie lub żałowała, że sama nie ma dzieci. W żadnym momencie film nie zachęca do identyfikacji ze strażniczką, skupiając się na relacji władzy między Niemką a więźniarką. Po porażce reżimu Liza czuje, że straciła ochronę i obawia się sprawiedliwości. 




Pasażerka, reż. Andrzej Munk, Witold Lesiewicz (1963)

Analizy rywalizacji dwóch głównych bohaterek w tekstach krytycznych wskazują na istotną rolę hierarchii obozowej w interpretacji dzieła ${ }^{44}$. Zofia Posmysz uważa niektóre $\mathrm{z}$ nich za słuszne, inne odrzuca jako niezgodne z własnym doświadczeniem. Uprzywilejowana pozycja Marty jako więźnia funkcyjnego pozwala jej na zachowanie podmiotowości. Skoro ta relacja opiera się na kontaktach Posmysz ze strażniczką Anneliese Franz, to warto przywołać wspomnienia ocalałej. Posmysz włączyła się w grę z Franz w Auschwitz-Birkenau na podstawie wcześniejszych doświadczeń z innymi członkami załogi SS. W wywiadzie-rzece opublikowanym w 2017 r., pisarka twierdzi nawet, że „manipulowała” strażniczkami i napuszczała jedne na drugie. Właściwie odczytując charakter Franz, unikała jej gniewu. Sekretarka ujrzała ludzką twarz SS-manki, gdy ta rozpłakała się po otrzymaniu informacji o śmierci męża na froncie. Po kilku chwilach wytarła łzy i odzyskała spokój ${ }^{45}$. Obie strony tej relacji władzy inaczej postrzegały swoją pozycję: Posmysz uważa, że SS-manka traktowała ją jako osobistą własność i kogoś całkowicie zależnego od własnej ochrony ${ }^{46}$. Jako anioł stróż rościła sobie prawo do ciała i duszy więźniarki. Posmysz próbuje przekazać tę dynamikę w Pasażerce. Słabość strażniczki ujawniła się po raz kolejny, gdy rozkazano jej, aby wzięła udział w selekcji węgierskich Żydów. Była zdruzgotana przymusowym udziałem w ludobójstwie. Według Posmysz Franz wyglądała na chorą i straciła nad sobą kontrolę. Dla więźniarki było jasne, że powinna ten epizod zachować w tajemnicy ${ }^{47}$.

Chęć kontrolowania interpretacji filmu przez Posmysz można postrzegać jako próbę zachowania integralności wspomnień. $Z$ tego powodu odrzuca ona teorię o homoerotycznym pożądaniu Lizy wobec Marty, zaproponowaną przez krytyka filmowego Konrada Eberhardta ${ }^{48}$. Uważa, że przez odwołanie do seksualności nie sposób wyjaśnić ludzkiego zachowania. Ponadto pisarka broni heteronormatywności Lizy, odwołując się do biografii Anneliese Franz. Posmysz rozprawia się także z inną interpretacją filmu jako ilustracji syndromu sztokholmskiego, twierdząc, że to nie ofiara czuła sympatię do prześladowczyni, lecz odwrotnie ${ }^{49}$. Sprzeciwiając się ,nieuzasad- 
nionym" odczytaniom filmu, Posmysz porównuje fikcjonalne postaci ze wspomnieniami. Ta strategia wskazuje jednak na to, że pisarka porzuciła wcześniej praktykowaną autofikcję na rzecz autorytetu świadka autobiograficznego.

Lęk przed normalizacją to oficjalne stanowisko partii i przyczyna antyniemieckiej kampanii w latach 60. (włączając w nią Krzyżaków Aleksandra Forda z 1960 r.). Nie poddając się propagandzie, w 1965 r. polscy biskupi apelowali o pojednanie i normalizację w liście do niemieckich biskupów. Do pewnego stopnia relacje między ofiarą a prześladowcą w przeszłości można nanieść na mapę powojennych lęków, niektóre z nich podsycała oficjalna propaganda: powrót Niemców po utracone mienie lub podważanie zachodniej granicy oraz strach przed kolejnym konfliktem zbrojnym. Nie mniej przerażające były koszmary o stanięciu oko w oko z katami. Z drugiej strony Marta nie jest zwykłą więźniarką, lecz osobą, która zachowała ograniczone możliwości decydowania o sobie i nie spadła na samo dno obozowej hierarchii. W końcu Pasażerka to nie tylko historia obozowa, lecz także prognoza przyszłości diady prześladowca/ofiara.

\section{Filmowy podręcznik terapeutyczny}

Jeśli potraktować analizowane filmy jako podręcznik terapeutyczny tworzący kategorie ocaleńców/pacjentów, należy zadać pytanie o możliwość wyleczenia. Jak łączy się uznanie czyjegoś statusu ofiary/osoby ocalałej z przezwyciężeniem traumy? Czy na pierwszy rzut oka skuteczna autoterapia Felicji wynika z natury krzywdy (przemoc seksualna, nieodwzajemnione uczucie, bycie świadkiem śmierci ukochanego), którą można połączyć z konkretnymi traumatyzującymi wydarzeniami? Z drugiej strony, podstępnej traumy Wiktora próżno szukać na liście rozpoznanych stresorów, dlatego też nie ma dla niego ratunku, a jego cierpienie psychiczne nie wzbudza sympatii. W podobny sposób „moment słabości” Lizy w czasie eksterminacji dzieci nie czyni jej „ofiarą traumy” ${ }^{50}$. Jednakże mechanizm przywołania, czyli przypadkowe spotkanie przywołujące wspomnienia o mrocznej przeszłości, przypomina mimowolne wyzwalanie symptomów posttraumatycznych. Chociaż Pasażerka przybliża życie wewnętrzne byłej strażniczki, nie można zignorować faktu, że stany mentalne Lizy po wojnie oparte są na ocenie osobowości prawdziwej strażniczki w obozie dokonanej przez Posmysz. Film zaprasza więc do badania psychologii sprawców.

Obserwacja behawioralna to niejedyna metoda przekazywania estetyki traumy. Nowoczesne środki transportu, liniowiec i samolot pasażerski, są metaforami pracy pamięci, podjętej przez bohaterów wyłączonych ze społecznego kontekstu. Podróż fizyczna to metafora podróży w czasie, zainicjowanej przez bodziec zewnętrzny: przypadkowe spotkanie lub strach przed lataniem. Przemierzanie przestrzeni to zaproszenie do podróży w czasie. W tym wymiarze różne formy rozliczenia z przeszłością są warunkiem koniecznym skutecznego procesu modernizacji. W kontraście do nieustającej traumatyzacji bohatera Lombardzisty Sydneya Lumeta (The Pawnbroker, 1965), oba filmy pozwalają na uzyskanie pewnego dystansu do przeszłości.

Filmy te powstały w kluczowym momencie historii PRL, kiedy należało pogodzić wymogi współczesności z szacunkiem dla cieniów przeszłości. W terminologii psychoanalitycznej reżyserzy wskazują na kobiecą/histeryczną etiologię 
traumy, podkreślając cierpienie kobiet lub utratę męskości straumatyzowanych mężczyzn ${ }^{51}$. Takie genderowe odwrócenia $\mathrm{w}$ następstwie traumy dobrze widać w Jak być kochana (Wiktor) i w Dziś w nocy umrze miasto (Vittorio). Filmowe traumy są skutkiem wydarzeń historycznych o znamionach nowoczesności: nalotu bombowego, obozu koncentracyjnego i zranienia psychicznego spowodowanego zderzeniem tradycyjnych wartości z realiami nowoczesnej wojny. Filmowcy podchodzą do fenomenu traumy psychicznej z perspektywy behawioralnej (obserwacja straumatyzowanych podmiotów ze znikomym komentarzem dyskursywnym) lub przedstawiają hermeneutyczną autoterapię za pomocą narracyjnych retrospekcji. Bohaterom powierzono zadanie poradzenia sobie z przeszłością bez pomocy z zewnątrz i grupy wsparcia. Co więcej, przeszłość pojawia się w monologu wewnętrznym (Jak być kochana, Pasażerka) lub w intymnej rozmowie z mężem (Pasażerka). Nie istnieją wspólnotowe rytuały, a przystosowanie się do powojennego życia wymaga uciszenia lub wyparcia przeszłości. W przypadku Lizy widok Marty (czy raczej kobiety ją przypominającej) skutkuje złamaniem narzuconego sobie zakazu wspominania służby w obozie koncentracyjnym. Obciążanie ocaleńców odpowiedzialnością za swój dobrostan psychiczny można odczytać jako przyznanie się do porażki, a także jako realistyczną ocenę dostępności wsparcia psychologicznego we wczesnym okresie powojennym. Krytycy zgodnie podkreślają rolę milczenia, spojrzenia w głąb siebie i wstydu powstrzymującego bohaterów (a także widownię) przed ujawnieniem całości doświadczeń okupacyjnych ${ }^{52}$. Co ciekawe, powracający w recenzjach powyższych obrazów film Resnais'go o Hiroszimie posłużył Cathy Caruth jako jeden z filarów teorii traumy ${ }^{53}$ trzy dekady po premierach polskich dzieł. Bohaterka Hiroszimy - francuska aktorka występująca w filmie fabularnym o pokoju - powierza japońskiemu kochankowi swój największy i najpilniej skrywany sekret: śmierć ukochanego - niemieckiego żołnierza - w dzień wyzwolenia. Chociaż znalazła słuchacza, postrzega to wyznanie jako zdradę wobec zmarłego. Dlatego centralnym problemem filmu jest według krytyczki pytanie: jak nie zdradzić (,, betray”) przeszłości ${ }^{54}$. W polskim kontekście brak jest takich przypadkowych słuchaczy dopuszczonych do sfery intymnej bohatera/bohaterki. Niemniej należy spojrzeć na francuski film zarówno jako na wzór estetyki traumy (cielesność, opowiadanie z miejsca, które w przeszłości było sceną traumy), jak i narracyjny schemat prowadzący do ujawnienia zranienia (przypadkowe spotkanie, osłabienie cenzury psychicznej).

Oprócz pokazywania życia psychicznego straumatyzowanych jednostek i pokłosia wojny filmy te można potraktować jako symptomy szerszych zjawisk w powojennej kulturze polskiej. Jak pogodzić potrzebę modernizacji kraju z obowiązkiem wspominania przeszłości? Jak przeciwdziałać propagandowo szkodliwej normalizacji stosunków polsko-niemieckich? Czyje krzywdy godne są upamiętnienia? Kto zarządza upamiętnieniem: kombatanci/ocaleńcy czy władze przyznające środki na produkcję filmową? Konflikt między modernizacją i upamiętnianiem rozwiązano kosztem unikania publicznych wyznań w Jak być kochana. Stawianie barier traumie i cnota samokontroli pozwalają przezwyciężyć niedostatki kultury terapeutycznej. Ideologiczne odrzucenie pojednania z Niemcami zachodnimi kontrastowało z propozycją wyrażoną w liście polskich biskupów. Nacisk położony na interpretowanie relacji z prześladowcą w filmie Pasażerka to zapowiedź następujących wydarzeń tej dekady: procesu frankfurckiego, listu polskich biskupów i trudnego do zrozu- 
mienia oporu władz wobec młodych niemieckich protestantów podejmujących działania pokutne w Państwowym Muzeum w Oświęcimiu ${ }^{55}$. Chociaż filmowe spotkanie ze strażniczką SS służy snuciu rozważań o psychologii sprawcy, spotkania te odbywały się zwykle na sali sądowej, gdzie wymierzenie kary po latach przeważało nad rozświetlaniem zakamarków duszy zbrodniarzy ${ }^{56}$. Analiza powyższych filmów przez pryzmat teorii traumy rzuca nowe światło na kwestie zdrowia psychicznego i osobistej odpowiedzialności oraz pozwala zrozumieć szersze trendy kulturowe

TOMASZ ŁYSAK

${ }^{1}$ Por. Antologia studiów nad trauma, red. T. Łysak, Universitas, Kraków 2015.

${ }^{2} \mathrm{~W}$ ostatnich latach krytycznemu oglądowi poddano kategorię świadka Zagłady. Por. T. Żukowski, Wielki retusz. Jak zapomnieliśmy, że Polacy zabijali Żydów, Wielka Litera, Warszawa 2018; Opowieść o niewinności: kategoria świadka Zaglady w kulturze polskiej (1942-2015), red. M. Hopfinger, T. Żukowski, Wydawnictwo IBL, Warszawa 2018; R. Sendyka, Od obserwatorów do gapiów. Kategoria „, bystanders" i analiza wizualna, ,Teksty Drugie" 2018, nr 3, s. 117-130; E. Janicka, Obserwatorzy uczestniczacy zamiast świadków i rama zamiast obrzeży. O nowe kategorie opisu polskiego kontekstu Zagłady, ,Teksty Drugie" 2018, nr 3, s. 131-147.

${ }^{3}$ Taka zmiana to przedmiot ambitnej, Lacanowskiej w duchu, analizy polskiego społeczeństwa po skończonej wojnie i Zagładzie zob. A. Leder, Prześniona rewolucja. Ćwiczenie z logiki historycznej, Wydawnictwo Krytyki Politycznej, Warszawa 2014.

${ }^{4}$ Reportaż Magdaleny Grzebałkowskiej - dziennikarki „Gazety Wyborczej” - nie jest historyczną panoramą wyzwolenia w 1945 r. Wprost przeciwnie to historia mówiona o codziennym życiu Niemców, Ukraińców i Polaków przesiedlonych z Kresów na Ziemie Odzyskane, a także żydowskich sierot w Otwocku. M. Grzebałkowska, Wojna i pokój, Wydawnictwo Agora, Warszawa 2015.

${ }^{5}$ M. Zaremba, Wielka trwoga. Polska 1944-1947. Ludowa reakcja na kryzys, Wydawnictwo Znak, Kraków 2012.

${ }^{6}$ J. T. Gross, Strach. Antysemityzm w Polsce tuż po wojnie: historia moralnej zapaści, Wydawnictwo Znak, Kraków 2006.

7 J. Bomba, M. Orwid, Psychiatric Study of World War II Survivors: The Case of Poland, w: The Politics of War Trauma: The Aftermath of World War II in Eleven European Countries, red. J. Withuis, A. Mooij, Aksant, Amsterdam 2010, s. 217-239.

${ }^{8}$ M. Lis-Turlejska, Sz. Szumiał, H. Okuniewska, Aktualny poziom objawów stresu potraumatycznego w próbie osób, które $w$ dzieciństwie przeżyly II wojnę światowa, ,Psychiatria Polska" 2012, tom 46, nr 2, s. 145-156; M. Lis-Turlejska, A. Łuszczyńska, Sz. Szumiał, Rozpowszechnienie PTSD wśród osób, które przeżyty II wojnę światowa w Polsce, „Psychiatria Polska" 2016, tom 50, nr 5, s. 923-934.

${ }^{9}$ S. Goltermann, Negotiating Victimhood in East and West Germany 1945-2005, w: The Politics of War Trauma, dz. cyt., s. 109-122.

${ }^{10}$ Wczesny okres heroicznego mitotwórstwa nie był wyjątkową cechą Polski, jak pokazuje Annet Mooij (The Aftermath of World War II: A Comparison, w: The Politics of War Trauma, dz. cyt., s. 271-286) w odniesieniu do 11 krajów europejskich.

${ }^{11}$ P. Zwierzchowski, Kino nowej pamięci. Obraz II wojny światowej $w$ kinie polskim lat 60., Wydawnictwo Uniwersytetu Kazimierza Wielkiego, Bydgoszcz 2013, s. 195-199.

${ }^{12}$ To zjawisko rozpoznano w literaturze medycznej jako spoleczne uznanie jako ofiary lub osoby ocalałej, dzięki któremu osoby odczuwające społeczne wsparcie i uznanie mają większe szanse przezwyciężenia PTSD (A. Maercker, J. Müller, Social Acknowledgment as a Victim or Survivor: a Scale to Measure a Recovery Factor of PTSD, ,Journal of Trauma Studies" 2004, t. 17, nr 4, s. 345-351). W polskim kontekście teorię tę zastosowały I. Drapała, M. Lis-Turlejska, Znaczenie społecznego uznania jako ofiary lub osoby ocalatej w przebiegu zaburzenia po stresie traumatycznym, „Psychiatria i Psychologia Kliniczna” 2013, tom 13, nr 4, s. 264-270.

${ }^{13} \mathrm{~J}$. Butler, Ramy wojny: kiedy życie godne jest opłakiwania?, tłum. A. Czarnacka, Instytut Wydawniczy Książka i Prasa: Teatr Drama- 
tyczny m.st. Warszawy im. Gustawa Holoubka, Warszawa 2011, s. 87.

${ }^{14}$ Robert McNamara służył jako analityk statystyczny Sił Powietrznych Stanów Zjednoczonych podczas II wojny, odpowiedzialny między innymi za zwiększenie strat wśród cywilnej populacji bombardowanych miast $\mathrm{w}$ Niemczech i w Japonii.

${ }^{15} \mathrm{~K}$. Vonnegut, Rzeźnia numer pięć, czyli Krucjata dziecięca, czyli Obowiąkowy taniec ze śmiercia, tłum. L. Jęczmyk; wiersze tłum. J. Jęczmyk, Zysk i S-ka, Poznań 2003. O strategii reprezentacji i miejscu tego dzieła w toczących się dyskusjach historycznych, a także źródłach inspiracji zob. A. Rigney, All This Happened, More or Less: What a Novelist Made of the Bombing of Dresden, „History and Theory" 2009, t. 48, nr 2, s. 5-24.

${ }^{16}$ W. G. Sebald, On the Natural History of Destruction, tłum. A. Bell, Random House, New York 1999.

${ }^{17}$ Klempererowi udało się przeżyć dzięki postawie żony, ,Aryjki”, która nie opuściła go przez całą wojnę.

${ }^{18}$ S. Goltermann, dz. cyt., s. 108.

${ }^{19}$ Ch. Classen, Between Political Coercion and Popular Expectations: Contemporary History on the Radio in the German Democratic Republic, w: Popular Historiographies in the $19^{\text {th }}$ and $20^{\text {th }}$ Centuries, red. S. Paletschek, Berghahn Books, Oxford, New York 2011, s. 97-98.

${ }^{20}$ J. Peltz, Człowiek w obliczu kataklizmu: ,Dziś $w$ nocy umrze miasto" $w$ realizacji, „Film” 1960, nr 48, s. 10.

${ }^{21}$ Symbolikę pociągów w upamiętnianiu Zagłady opisują O. B. Stier, Holocaust Icons: Symbolizing the Shoah in History and Memory, Rutgers University Press, New Brunswick 2015, i T. Presner, Mobile Modernity: Germans, Jews, Trains, Columbia University Press, New York 2007.

${ }^{22} \mathrm{~W}$ kwestii zasadności historycznego porównania obu miejsc masowej zagłady cywilów zob. A. Rigney, dz. cyt., s. 6-7.

${ }^{23}$ J. Peltz, dz. cyt., s. 11.

${ }^{24}$ Żaneta Jamrozik podkreśla, że „Felicja” to imię postaci, a widzowie nigdy nie poznają prawdziwego imienia bohaterki, How to be an Actress (in Poland): The Figure of the Actress in Wojciech Jerzy Has's "How to be Loved” (1962), „Studies in Eastern European Cinema” 2014, t. 4, nr 1, s. 29-46.

${ }^{25}$ Rolę fetyszyzmu narracyjnego w świadectwach traumy opisał E. Santner, History Beyond the Pleasure Principle: Some Thoughts on the Representation of Trauma, w: Probing the Limits of Representation: Nazism and the , Fi- nal Solution", red. S. Friedlander, Harvard UP, Cambridge 1992, s. 143-154.

${ }^{26}$ L. S. Brown, Not Outside the Range: One Feminist Perspective on Psychic Trauma, w: Trauma: Explorations in Memory, red. C. Caruth, Johns Hopkins UP, Baltimore 1995, s. $100-112$

${ }^{27} \mathrm{Na}$ negatywne uczucia Wiktora zwraca uwage Łukasz Maciejewski, Od Ofelii do Felicji. Arcydzieło odkryte na nowo, „Dekada Literacka” 2010, nr 4-5, s. 220.

${ }^{28} \mathrm{O}$ społecznym znaczeniu picia wódki w Polsce, postawach władz wobec osób z problemem alkoholowym i monopolizacji produkcji alkoholu zob. M. Gorsky i in., Anti-alcohol Posters in Poland, 1945-1989: Diverse Meanings, Uncertain Effects, „American Journal of Public Health" 2010, t. 100, nr 11, s. 2059-2069. Autor dowodzi, że ośrodki leczenia alkoholizmu wprowadzone w 1956 r. nie dawały dostępu do terapii medycznej i psychiatrycznej, stawiając na pracę jako formę leczenia (s. 2061). Olga Amsterdamska twierdzi, że wśród wielu interpretacji spożywania alkoholu w polskiej literaturze należy zwrócić uwagę na strategię Marka Hłaski, który postrzega pijaństwo jako symptom problemów moralnych. Drinking as a Political Act: Images of Alcoholism in Polish Literature, 1956-89, w: Images of Disease: Science, Public Policy and Health in Post-war Europe, red. I. Löwy, J. Krige, European Commission, Luxembourg 2001, s. 317.

${ }^{29} \mathrm{O}$ różnicach w postrzeganiu spożywania wódki i koniaku zob. A. Klim, Seks, sztuka i alkohol: zycie towarzyskie lat 60., Dom Wydawniczy PWN, Warszawa 2013, s. 79-80, 84.

${ }^{30} \mathrm{O}$ różnicach płciowych w spożywaniu alkoholu podczas wojny zob. K. Janicki, Pijana wojna: alkohol podczas II wojny światowej, Erica, Warszawa 2012. Autorzy podkreślają, że kampanie antyalkoholowe skierowane były do mężczyzn, zob. J. Laskowska-Otwinowska, Community and Individual Changes in Propaganda against Alcoholism in Poland from 1945 to the 1990s, w: Images of Disease, dz. cyt., s. 332.

${ }^{31}$ Ż. Jamrozik, dz. cyt., s. 43.

32 J. Lacan, The Four Fundamental Concepts of Psychoanalysis, tłum. A. Sheridan, red. J.-A. Miller, Penguin Books, London 1979.

${ }^{33}$ A. Kępiński, Motywy polskiego pijaństwa $i$ środki zaradcze, w: Alkohol w kulturze i obyczaju, red. J. Górski, K. Moczarski, Wiedza Powszechna, Warszawa 1972, s. 52-53.

${ }^{34}$ Tamże, s. 55.

${ }^{35}$ Tamże, s. 56-57.

${ }^{36} \mathrm{~K}$. Eberhardt, Opowieść o czasie wewnętrznym, „Film” 1963, nr 3, s. 5 
${ }^{37}$ J. Leociak, ,Nie chcę ludziom na śmiech się pokazać, że Żydów u siebie chowatem... " Sprawa Zdzisława i Haliny Krzyczkowskich, ,Zagłada Żydów. Studia i Materiały” 2008, tom 8, s. 324-366.

${ }^{38}$ Tak długie ukrywanie się Wiktora w jednym miejscu było odstępstwem od normy; Żydzi często zmieniali kryjówki, gdy tylko pojawiało się najmniejsze choćby zagrożenie zdradą lub dekonspiracją. Ich uzależnienie od gospodarzy rodziło konflikty i tworzyło napięcie.

${ }^{39}$ S. Janicki, Felicja nikogo nie oskarża, przeciwko nikomu się nie buntuje - mówi Barbara Krafftówna, bohaterka filmu ,Jak być kochanq̨", „Film” 1963, nr 3, s. 6.

${ }^{40} \mathrm{O}$ sytuacji kobiet pod okupacją zob. D. Kałwa, Przemoc i zapomnienie. Druga wojna światowa z perspektywy ptci kulturowej, w: Kobiety i historia. Od niewidzialności do sprawczości, red. K. Bałżewska, D. Korczyńska-Partyka, A. Wódkowska, Wydawnictwo Uniwersytetu Gdańskiego, Gdańsk 2015, s. 27-43.

${ }^{41} \mathrm{Na}$ temat przekształceń własnej biografii na potrzeby omawianego tekstu zob. A. Żyła, $A u$ tofikcja jako sposób opowiadania siebie na przykładzie „Pasażerki” Zofii Posmysz, w: Kobiety i historia, dz. cyt., s. 249-264.

${ }^{42}$ Aleksandra Żyła zwraca uwagę na mechanizm traumatycznego przypomnienia, wywołany tym przypadkowym spotkaniem. Posługując się konwencją autofikcji pisarka przypisała to spotkanie oprawczyni w Pasażerce. Zob. Autofikcja jako sposób... dz. cyt., s. 256.

${ }^{43} \mathrm{~S}$. Mohamed, Of Monsters and Men: Perpetrator Trauma and Mass Atrocity, „Columbia Law Review” 2015, t. 115, nr 5, s. 1157-1216.

${ }^{44}$ Monika Talarczyk-Gubała sygnalizuje temat relacji homoerotycznej w literaturze, przechodzi jednak od razu do relacji między kobietami. Zob. Więźniarki i polityka: „Ostatni etap” Wandy Jakubowskiej i inne filmy obozowe w perspektywie studiów kobiecych $w$ badaniach Holokaustu, „Kwartalnik Filmowy” 2015, nr 92, s. 153.

${ }^{45}$ M. Wójcik, Zofia Posmysz. Królestwo za mgła, Znak, Kraków 2017, s. 173-174.

${ }^{46}$ Tamże, s. 187.

${ }^{47}$ Tamże, s. 189-190.

${ }^{48}$ K. Eberhardt, Przeciw niepamięci, „Film” 1963, nr 40, s. 4-5.
${ }^{49}$ M. Wójcik, dz. cyt., s. 201-206.

${ }^{50}$ Taką zrównującą diagnozę stawia jednak Żyła, twierdząc, że Lizę i Martę w powieści [ł]aczzy wspólne doświadczenie traumy (Autofikcja jako sposób... dz. cyt., s. 253). W późniejszym wywodzie krytyczka doprecyzowuje, że chodzi o powojenne symptomy psychosomatyczne i naznaczenie obozem (s. 261-263).

${ }^{51}$ Agnieszka Morstin nazywa Wiktora ,dzieck[iem]" (...) przebran [ym] za mężczyznę. Taż, Mocne filmy i głębokie kompleksy: „Róża” Wojtka Smarzowskiego wobec „Jak być kochana” Wojciecha J. Hasa, „Kwartalnik Filmowy" 2012, nr 77-78, s. 207.

52 Tamże, s. 206, 208; R. Kosewski, Pamięć o Holocauście w kinie fabularnym: (analiza retrospekcji filmowej na podstawie filmów „Pasażerka” $i$, The Pawnbroker”), „Zagłada Żydów. Studia i Materiały” 2009, nr 5, s. 341. Analizę opery opartej na historii obozowej Michał Bristiger kończy pytaniem: Dlaczego Pasażerka milczała, było już przecież dawno po wojnie? Tenże, ,,Pasażerka”- opera o Auschwitz, czyli o zjawie w dzisiejszym świecie, ,Zeszyty Literackie" 2009, nr 3, s. 119.

${ }^{53}$ C. Caruth, Unclaimed Experience. Trauma, Narrative, and History, The Johns Hopkins University Press, Baltimore 1996, s. 25-56.

${ }^{54}$ Tamże, s. 27.

${ }^{55}$ Grupy niemieckiej młodzieży biorącej udział w programie ,znaki pokuty” próbowały zadośćuczynić za grzechy rodziców, wykonując pracę na rzecz byłych obozów koncentracyjnych w Oświęcimiu, na Majdanku i w Stutthofie. Marcin Majowski (Polska Ludowa zaprasza. Polityka turystyczna w czasach Edwarda Gierka, Wydawnictwo Trio, Warszawa 2008, s. 47, 120) uważa, że negatywne reakcje na to przedsięwzięcie miały na celu podsycanie polskich traum wojennych i służyły zapobieżeniu jakichkolwiek form pogodzenia się z Niemcami.

${ }^{56}$ Wywiady Leona Goldensohna (Rozmowy norymberskie, thum. A. Weseli-Ginter, oprac. i wstęp R. Gellately, Amber, Warszawa 2005) przeprowadzone podczas procesu norymberskiego to interesujący wyjątek od tej reguły. 